Article

\title{
Water Limitation in Forest Soils Regulates the Increase in Weathering Rates under Climate Change
}

\author{
Salim Belyazid ${ }^{1, * \mathbb{D}}$, Cecilia Akselsson ${ }^{2}$ and Giuliana Zanchi ${ }^{2}$ \\ 1 Department of Physical Geography, Stockholm University, 10691 Stockholm, Sweden \\ 2 Department of Physical Geography and Ecosystem Science, Lund University, 22002 Lund, Sweden; \\ cecilia.akselsson@nateko.lu.se (C.A.); giuliana.zanchi@nateko.lu.se (G.Z.) \\ * Correspondence: salim.belyazid@natgeo.su.se
}

Citation: Belyazid, S.; Akselsson, C.; Zanchi, G. Water Limitation in Forest Soils Regulates the Increase in Weathering Rates under Climate Change. Forests 2022, 13, 310. https://doi.org/10.3390/f13020310

Academic Editor: Keizo Hirai

Received: 22 December 2021

Accepted: 18 January 2022

Published: 14 February 2022

Publisher's Note: MDPI stays neutral with regard to jurisdictional claims in published maps and institutional affiliations.

Copyright: (C) 2022 by the authors. Licensee MDPI, Basel, Switzerland. This article is an open access article distributed under the terms and conditions of the Creative Commons Attribution (CC BY) license (https:// creativecommons.org/licenses/by/ $4.0 /)$.

\begin{abstract}
Climate change is generally expected to have a positive effect on weathering rates, due to the strong temperature dependence of the weathering process. Important feedback mechanisms such as changes in soil moisture, tree growth and organic matter decomposition can affect the response of weathering rates to climate change. In this study, the dynamic forest ecosystem model ForSAFE, with mechanistic descriptions of tree growth, organic matter decomposition, weathering, hydrology and ion exchange processes, is used to investigate the effects of future climate scenarios on base cation weathering rates. In total, 544 productive coniferous forest sites from the Swedish National Forest Inventory are modelled, and differences in weathering responses to changes in climate from two Global Climate Models are investigated. The study shows that weathering rates at the simulated sites are likely to increase, but not to the extent predicted by a direct response to elevated air temperatures. Besides the result that increases in soil temperatures are less evident than those in air temperature, the study shows that soil moisture availability has a strong potential to limit the expected response to increased temperature. While changes in annual precipitation may not indicate further risk for more severe water deficits, seasonal differences show a clear difference between winters and summers. Taking into account the seasonal variation, the study shows that reduced soil water availability in the summer seasons will strongly limit the expected gain in weathering associated with higher temperatures.
\end{abstract}

Keywords: base cations; mineral weathering; forest soils; climate change; dynamic modelling

\section{Introduction}

The use of the natural environment for economic activity has led to increasingly evident environmental impacts. On the global scale, these impacts are manifested through the exceedance of the planetary boundaries [1], including climate change [2]. Awareness of these impacts is driving a shift away from conventional, linear resource use to a circular, bio-based economy [3]. Sweden is engaging in an ambitious national strategy to have no net emission of greenhouse gases by the year 2045 (The Climate Act, 2017:720), supported by a national strategy for a bio-based economy [4]. While forestry is already today a key sector in this strategy [5], a further increase in biomass production from forestry is needed to meet the stated goals $[6,7]$.

Higher levels of biomass harvesting from forests may, however, compromise the sustainability of forest ecosystems [8]. As in other parts of Europe, Swedish forests have been exposed to acid atmospheric deposition $[9,10]$, the effects of which can still be seen in acidified forest soils [11-13]. Forest soil acidification may be further exacerbated by the removal of alkaline cations though biomass harvesting [11,14-16]. Iwald et al. [11] show that the net extraction of base cations through forest harvesting in spruce forests causes higher soil acidification than the current acid deposition. Using production forecasts from Claesson [17], Iwald et al. [11] conclude that forestry will be the major source of soil 
acidification in the coming 100 years. These findings are supported by mass balance studies by $[18,19]$ demonstrating net long-term losses of base cations under different harvesting intensities, even under climate change scenarios leading to higher weathering rates.

Base cation release through mineral weathering sustains the long-term supply of base cations [20]. In light of increasing temperatures following climate change, this compensation potential is anticipated to increase as weathering is responsive to temperature changes [21-23]. Akselsson et al. [19] used the PROFILE model, which includes an Arrhenius dependence of weathering rates on temperature, to show that weathering rates would increase by $20 \%$ to $33 \%$ in Swedish soils in response to the expected warming by between $2.2^{\circ} \mathrm{C}$ and $3.3^{\circ} \mathrm{C}$ over the coming 50 years. While this increase falls short of the expected increase in losses through whole tree harvesting at $66 \%$ as compared to conventional stem harvesting [19], it is in line with the independent finding of Aherne et al. [20] using a different method in comparable ecosystems. In a separate assessment using a cascade of numerical models for climate, vegetation and weathering, Godderis et al. showed that silicate weathering is likely to increase in response to changes in climate over the next 100 years, and that pedon scale hydrological patterns are likely to have a decisive role in regulating this response [24]. Besides its response to temperature, mineral weathering is regulated through a range of other factors, many of which involve geochemical, physical, as well as biological processes [22,25-29]. The potential acceleration of weathering rates in response to higher temperatures can be cancelled by drier soil conditions, which in turn can be driven by increased plant transpiration following higher plant growth. At the same time, higher plant growth can produce more litterfall, thereby increasing the concentrations of organic radicals, lowering base cation concentrations through uptake, and lowering $\mathrm{pH}$, thus further promoting weathering. When considering the different pathways through which climatic changes can affect weathering, it becomes less evident whether the net effect will be positive or negative.

To investigate the net response of weathering to climatic changes, it is necessary to account for different processes simultaneously. For this, integrated ecosystem models are well suited tools. In this study, we use the integrated forest ecosystem model ForSAFE $[14,30,31]$ to evaluate the processes by which climate change affects mineral weathering in forest soils, and identify instances where these processes amplify or cancel out each other. The study focuses specifically on the effect of higher temperatures and different precipitation patterns on mineral weathering rates in the unsaturated zone up to the year 2100. It will test the hypothesis that a reduction in water availability will limit the expected increase in weathering expected from higher temperatures. To account for the uncertainty of future climate trajectories, modelled data from two climate models with different projections are used.

\section{Materials and Methods}

\subsection{The ForSAFE Model}

ForSAFE is an integrated forest ecosystem model that simulates the interlinked biogeochemical cycles of water, carbon, nutrients and other elements [30-33]. The model calculates time derivatives of the mass balance of carbon, nitrogen, calcium, magnesium, potassium, sodium, chlorine, and aluminium as they move between minerals, ion exchange sites, soil solution, living biota and soil organic matter. The release of base cations through the weathering of minerals in ForSAFE is based on the PROFILE model [22]. Weathering happens through four pathways regulated by soil solution acidity, moisture, partial $\mathrm{CO}_{2}$ pressure and the concentration of organic radicals. The total weathering flux for one mineral is given as the sum of the four independent mineral dissolution pathways (Equation (1)).

$$
r=F_{H}(T) \cdot k_{H} \cdot \frac{\left[H^{+}\right]^{n_{H}}}{f_{H}}+F_{\mathrm{H}_{2} \mathrm{O}}(T) \cdot k_{\mathrm{H}_{2} \mathrm{O}} \cdot \frac{1}{f_{\mathrm{H}_{2} \mathrm{O}}}+F_{\mathrm{CO}_{2}}(T) \cdot k_{\mathrm{CO}_{2}} \cdot \frac{\left[P_{\mathrm{CO}_{2}}\right]^{n_{\mathrm{CO}_{2}}}}{f_{\mathrm{CO}_{2}}}+F_{R}(T) \cdot k_{R} \cdot \frac{\left[R^{-}\right]^{n_{R}}}{f_{R}}
$$

where $F_{i}(T)$ is the Arrhenius temperature response given by Equation (2), for each dissolution pathway $i$ associated with $\mathrm{H}^{+}, \mathrm{H}_{2} \mathrm{O}, \mathrm{CO}_{2}$ and organic radicals $R^{-}$. Each pathway 
can be subject to a retardation function $\left(f_{i}\right)$, which are here only assumed to be active for weathering by $\mathrm{H}^{+}$and $\mathrm{H}_{2} \mathrm{O}$.

$$
F_{i}(T)=e^{\frac{-\left(E_{A}\right)_{i}}{R}\left(\frac{1}{T}-\frac{1}{T_{0}}\right)}
$$

where $E_{A}$ is the activation energy of mineral $i, R$ is the universal gas constant, $T_{0}$ is the reference temperature set to $281 \mathrm{~K}$ [22] and $T$ is the independent temperature. The total weathering rate of soil horizon is then given by Equation (3):

$$
R_{w}=\sum_{i=1}^{\text {minerals }} r_{i} \cdot A_{w} \cdot x_{i} \cdot \theta \cdot z
$$

where $A_{w}$ is the total weatherable area according to Phelan et al. [34], $x_{i}$ is the fraction of the weatherable area fraction of mineral $i, \theta$ is soil moisture, and $z$ the thickness of the soil layer.

The Arrhenius temperature response function (Equation (2)) describes how an increase in temperature is expected to drive an increase in the mineral dissolution rates. The responses are shown for selected activation energies in Figure 1.

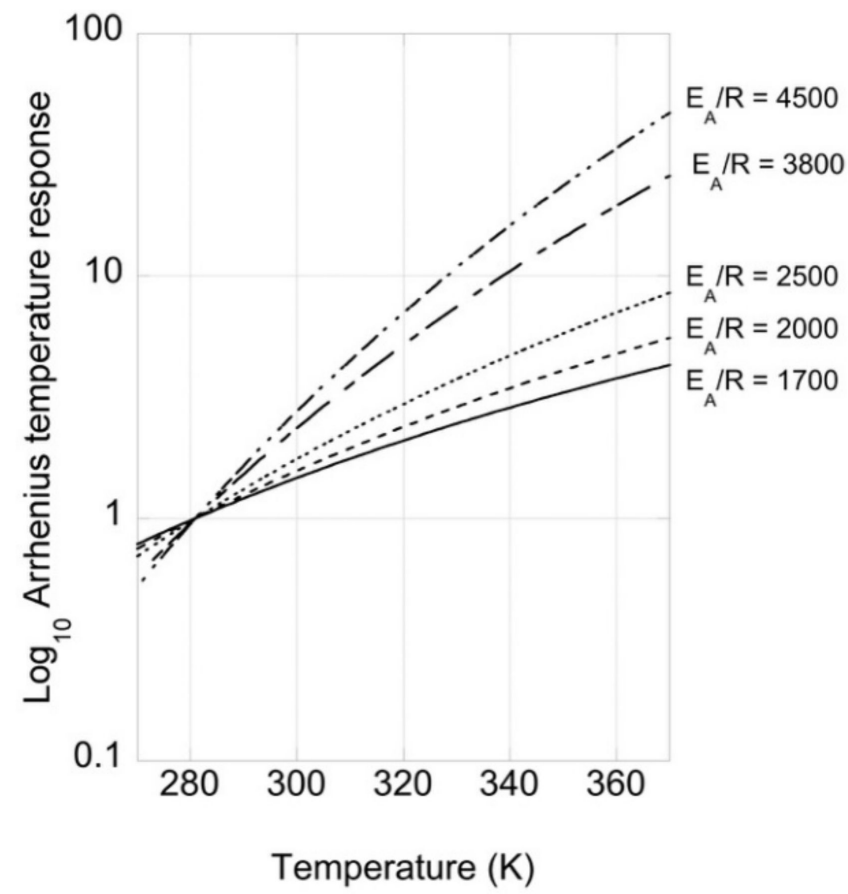

Figure 1. Arrhenius temperature response functions of weathering rates for different mineral activation energies $\left(\mathrm{kJ} \cdot \mathrm{mol}^{-1} \cdot \mathrm{K}^{-1}\right)$.

All weathering pathways will individually increase with higher temperature (Equation (1), Figure 1). At the same time, the total weathering rate will be directly regulated by soil moisture (Equation (3)). Additionally, the retardation functions can be promoted by lower soil moisture as this increases the concentrations of base cations and aluminum. In ForSAFE, tree cover physiological processes and organic matter decomposition are modelled endogenously. This allows the model to internally account for changes in soil moisture and solute concentrations in response to changes in climate, but also internal changes in growth, uptake, respiration and mineralization in a way that previous studies with the PROFILE model were not able to capture directly [19]. The numerical parametrization of the individual weathering pathways for the minerals present in the simulated soils can be found in Akselsson et al. [19]. 


\subsection{Study Area}

This study comprises forest sites from all parts of Sweden, expect the mountainous region in the northwest and the two islands Öland and Gotland in the southeast. The latitudinal range goes from $55^{\circ} \mathrm{N}$ to $69^{\circ} \mathrm{N}$, spanning various climatic and different vegetations zones: the boreal zone above around $60^{\circ}$, the nemoral zone in the southernmost part and boreonemoral zone in between.

The bedrock is dominated by igneous and metamorphic rocks, mainly granites and gneisses, but sedimentary rocks are also common. Sweden was covered by ice during the last ice age, and the soils thus consist to a large extent of glacial till and glacifluvial deposits. These soils originate mainly from nutrient poor and slow weathering parent material like granite and gneiss, but often with different compositions than the underlying bedrock due to the movement of till during the recent glaciation [18]. The soils modelled are generally rather poor, with podzol as the most common soil type. Acidifying precipitation has further deteriorated the soil's nutritional status, especially in southwest Sweden with the highest atmospheric deposition levels [13]. However, calcite-rich soils originating from sedimentary bedrock can be found in some areas, e.g., in the southernmost part of Sweden. Those areas are often used for agriculture rather than forestry, making them only marginally present in the simulated database.

Forest land covers more than two thirds of the land area, and most of the forest is managed. The most common tree species are Norway Spruce (Picea abies (L.) H. Karst.) and Scots Pine (Pinus sylvestris L.). Spruce is dominating in the south, whereas pine is the most common species in the north. The most common deciduous species is birch (Betula pubescens Ehrh. and Betula pendula Roth). Less common deciduous species are European beech (Fagus sylvatica L.), trembling aspen (Populus tremula L.) and pedunculate oak (Quercus robur L.).

\subsection{Forest Sites Data}

ForSAFE was applied to 544 managed coniferous forest sites in Sweden [35]. Soil data was originally compiled by Warfvinge and Sverdrup [36] and complemented by Alveteg [37] with data from the Swedish National Forest Inventory [38]. Unlike the study by Alveteg [37], only soil data was used as input and not data on tree growth, as ForSAFE internally calculates tree growth, organic matter decomposition and hydrology. The modelled soils represent the rooting zones and are contained within a depth of up to $50 \mathrm{~cm}$. All soils are podzols, with little or no similarity to the mineralogy of the bedrock due to the movement of silt during the recent glaciation [39]. The respective thickness, texture and total elemental analysis (used to calculate mineralogy) for the different soil layers at each site were derived from data provided by the Swedish Geological Survey and the Swedish National Forest Inventory [39].

ForSAFE requires time series data for atmospheric deposition and climate for the simulation period between the years 1900 and 2100. Data for atmospheric deposition for $\mathrm{NH}_{4}{ }^{+}, \mathrm{NO}_{3}{ }^{-}$and $\mathrm{SO}_{4}{ }^{2-}$ were derived from the EMEP model simulations [40], adopting the historical trends from [9] and the future projections following the emissions scenario of the current legislation of the revised Gothenburg protocol of the Long Range Transboundary Air Pollution convention (LRTAP). The atmospheric deposition data for the $\mathrm{Ca}^{2+}, \mathrm{Mg}^{2+}$, $\mathrm{K}^{+}, \mathrm{Na}^{+}$and $\mathrm{Cl}^{-}$came from recent output by the MATCH model [41] and held constant over the simulation period.

Forest stand history and future management were derived from current recommendations for spruce and pine forests in the management tables (gallringsmallar) developed by the Swedish Forest Agency and indications given by the model INGVAR [42-44]. According to these sources the rotation length and number of thinnings vary according to the geographical location of the stand and the site productivity. The forest rotation length was further corrected based on recorded stand age from the National Forest Inventory [35]. Forest management dictates the historical and expected dates and intensities of harvesting and thinning at each modelled forest stand. 


\subsection{Climate}

Precipitation and temperature data for the period between 1961 and 2008 were derived from historical records from the weather stations of the Swedish Meteorological Institute (SMHI), and spatially interpolated to the exact coordinates of the simulated sites [45]. Data on global radiation time-series from the NCEP/NCAR's reanalysis project were converted to photosynthetically active radiation (PAR) using SMHI's STRÅNG model [45]. The site specific climate data for the period 1961 to 2008 was then used to calibrate the historical and future climate trends from two Global Climate Models (GCM): the Max Plank Institute's ECHAM5 GCM (hereafter referred to as ECHAM) and the National Center for Atmospheric Research's CCSM3 GCM (hereafter referred to as CCSM). The SRES A2 story line was used for the future climate.

Although using the same emissions scenario, the two climate models produce markedly different projections of temperature and precipitation. ECHAM predicts a stronger increase in winter temperatures (December to February), while CCSM predicts more markedly warmer summers (June to August) (Figure 2). Both models predict wetter winters, but different geographical patterns in summer precipitation (Figure 2). While ECHAM divides Sweden into an evenly drier south and wetter north during the summers, CCSM foresees wetter inland areas and drier coastal areas, with no apparent north to south pattern (Figure 2).

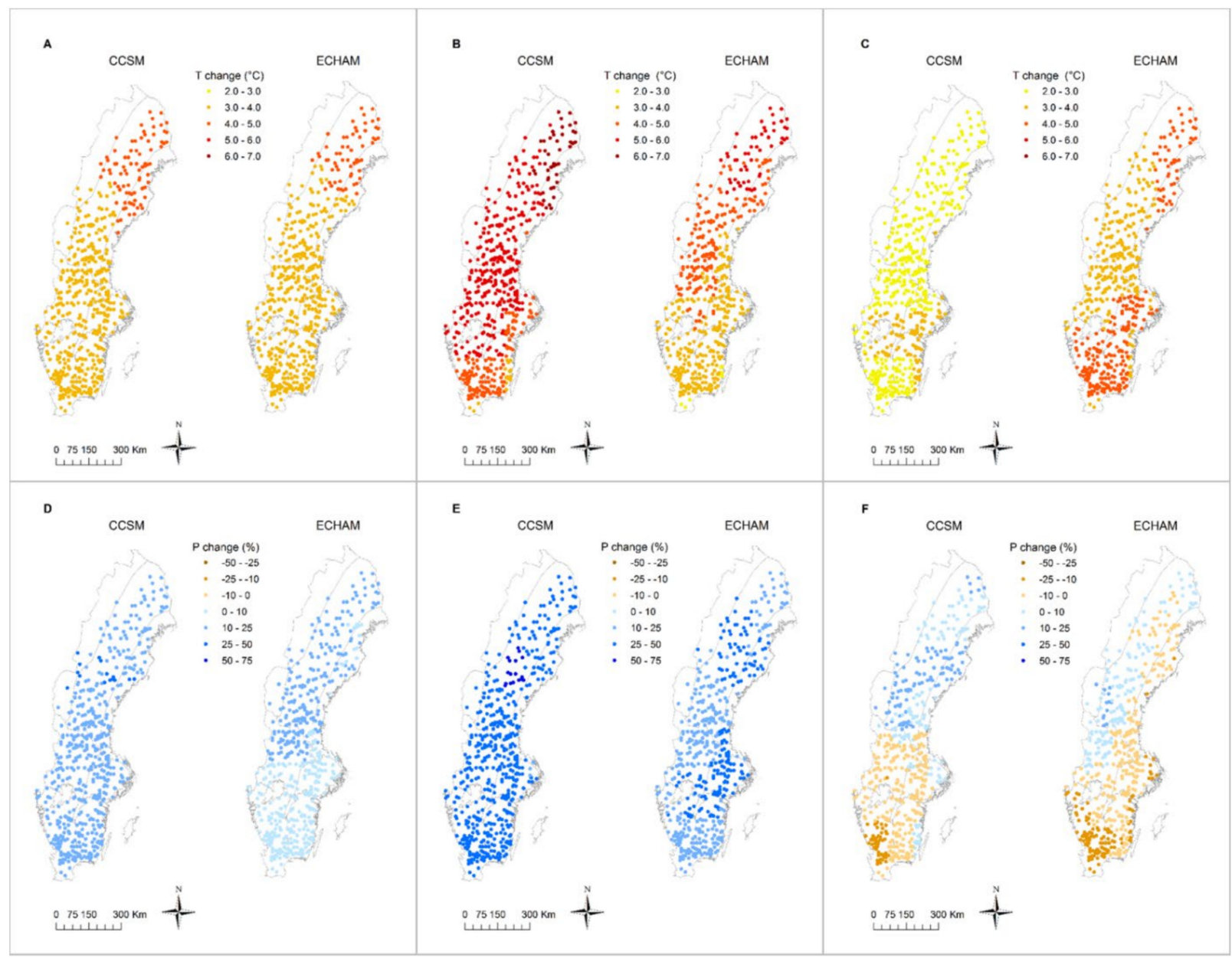

Figure 2. Differences in air temperature $(\mathrm{T})$ and precipitation $(\mathrm{P})$ between climate change projections by the CCSM and ECHAM models for the period 2071-2100 as compared to a hypothetical future with no change from the reference period of 1981-2010 (adapted from [35]). The upper row shows: (A) - the difference in mean annual temperature $\left({ }^{\circ} \mathrm{C}\right),(\mathbf{B})$ - mean winter temperature $\left({ }^{\circ} \mathrm{C}\right)$ and $(\mathbf{C})$ mean summer temperature $\left({ }^{\circ} \mathrm{C}\right)$. The lower row shows the corresponding difference in precipitation (\%) annually (D), for the winter season (E) and for summer (F). 
For the purpose of the study, the ForSAFE model was run with three climate scenarios: 1-the baseline scenario assumes no further change compared to the reference period of 1981-2010, 2-the CCSM scenario follows the climate projections of the CCSM model, and 3-the ECHAM scenario follows the projections of the ECHAM model. All comparative results are shown as averages for the period 2071-2100.

\section{Results}

\subsection{Annual Weathering Rates}

The rates of base cation release from weathering vary greatly between sites under the baseline scenario, but with no clear large scale geographical patterns, except for the relatively lower rates in central Sweden due to poorer parent material (Figure 3). The average weathering rate under the base line scenario is $0.35 \mathrm{keq} \cdot \mathrm{ha}^{-1} \cdot \mathrm{year}^{-1}$, with the median at $0.24 \mathrm{keq} \cdot \mathrm{ha}^{-1} \cdot \mathrm{year}^{-1}$ (Table 1 ). The variability is relatively large, with the standard deviation at $0.4 \mathrm{keq} \cdot \mathrm{ha}^{-1} \cdot \mathrm{year}^{-1}$, and the skewness strongly positive at 4.43 . Under future climate change, the average annual weathering rate is expected to increase to $0.43 \mathrm{keq} \cdot \mathrm{ha}^{-1} \cdot \mathrm{year}^{-1}$ and $0.44 \mathrm{keq} \cdot \mathrm{ha}^{-1} \cdot \mathrm{year}^{-1}$, respectively, using the CCSM and ECHAM climate scenarios. The standard deviation will slightly increase to 0.48 and 0.49 , respectively, under CCSM and ECHAM (Table 1). The expected average annual weathering rates in response to climate change do not show any clear geographical patterns corresponding to the expected air temperature increase, with increases simulated in all regions (Figure 2). The region in central Sweden with a high frequency of lower weathering rates is consistent through all three scenarios (Figure 3).

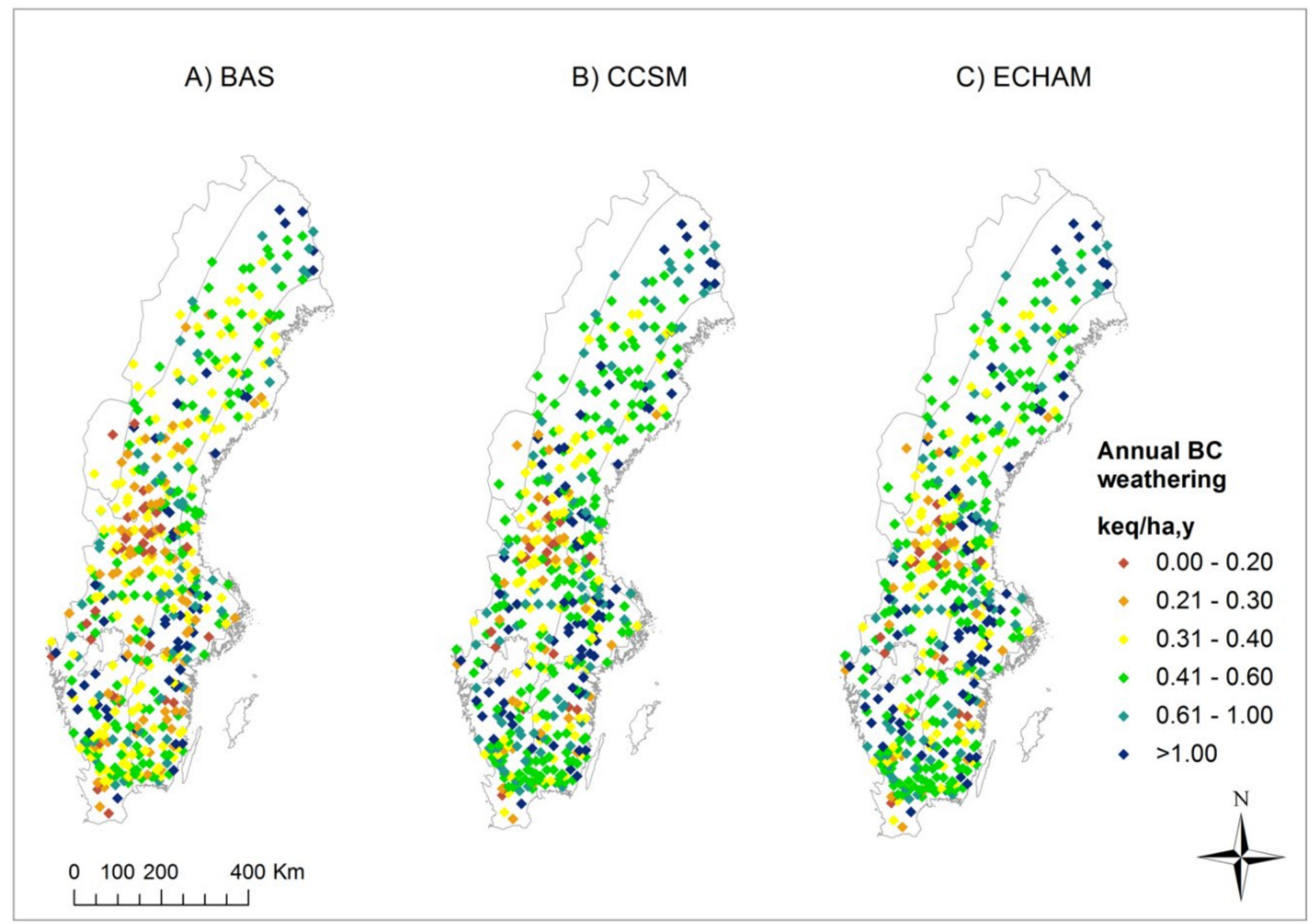

Figure 3. Geographical distributions of mineral weathering rates (keq $\cdot \mathrm{ha}^{-1} \cdot \mathrm{year}^{-1}$ ) in the unsaturated soil at 544 productive forest sites. (A) — without changes in climate, (B) - using CCSM climate projections, and (C)—using ECHAM climate projections. 
Table 1. Statistical summary of the release rates of $\mathrm{Ca}^{2+}+\mathrm{Mg}^{2+}+\mathrm{K}^{+}+\mathrm{Na}^{+}$from mineral weathering (called weathering rates) in the unsaturated soil (between $45 \mathrm{~cm}$ and $50 \mathrm{~cm}$ depth) at 544 forested sites.

\begin{tabular}{|c|c|c|c|}
\hline & 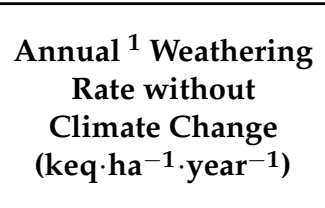 & $\begin{array}{c}\text { Annual }^{2} \\
\text { Weathering Rate } \\
\text { with Future Climate } \\
\text { According to CCSM } \\
\left(\mathrm{keq} \cdot \mathrm{ha}^{-1} \cdot \text { year }^{-1} \text { ) }\right.\end{array}$ & $\begin{array}{c}\text { Annual }{ }^{2} \text { Weathering Rate } \\
\text { with Future Climate } \\
\text { According to ECHAM } \\
\text { (keq.ha } \text { he }^{-1} \cdot \text { year }^{-1} \text { ) }\end{array}$ \\
\hline Minimum & 0.05 & 0.05 & 0.05 \\
\hline Maximum & 4.42 & 5.61 & 5.70 \\
\hline Mean & 0.35 & 0.43 & 0.44 \\
\hline Median & 0.24 & 0.30 & 0.29 \\
\hline Std Deviation & 0.40 & 0.48 & 0.49 \\
\hline Skewness & 4.43 & 4.66 & 4.65 \\
\hline
\end{tabular}

${ }^{1}$ Average annual release of $\mathrm{Ca}^{2+}+\mathrm{Mg}^{2+}+\mathrm{K}^{+}+\mathrm{Na}^{+}\left(\mathrm{keq} \cdot \mathrm{ha}^{-1} \cdot \mathrm{year}^{-1}\right)$ through mineral weathering for the period 2071-2100 under a hypothetical future with no change in climate compared to the period 1981-2010. ${ }^{2}$ Average annual release of $\mathrm{Ca}^{2+}+\mathrm{Mg}^{2+}+\mathrm{K}^{+}+\mathrm{Na}^{+}\left(\mathrm{keq} \cdot \mathrm{ha}^{-1} \cdot\right.$ year $\left.^{-1}\right)$ through mineral weathering for the period 2071-2100 under a changing climate according to climate forecasts by CCSM and ECHAM.

\subsection{Annual Change in Weathering Following Climate Change}

Weathering rates are expected to increase consistently throughout the country and under both climate change scenarios (Figure 4). Expectedly, the geographical pattern of the annual increase in weathering mirrors relatively closely the increase in annual soil temperature (Figure 4), but less so the increase in air temperature (Figure 2).

\section{A) CCSM - BAS}

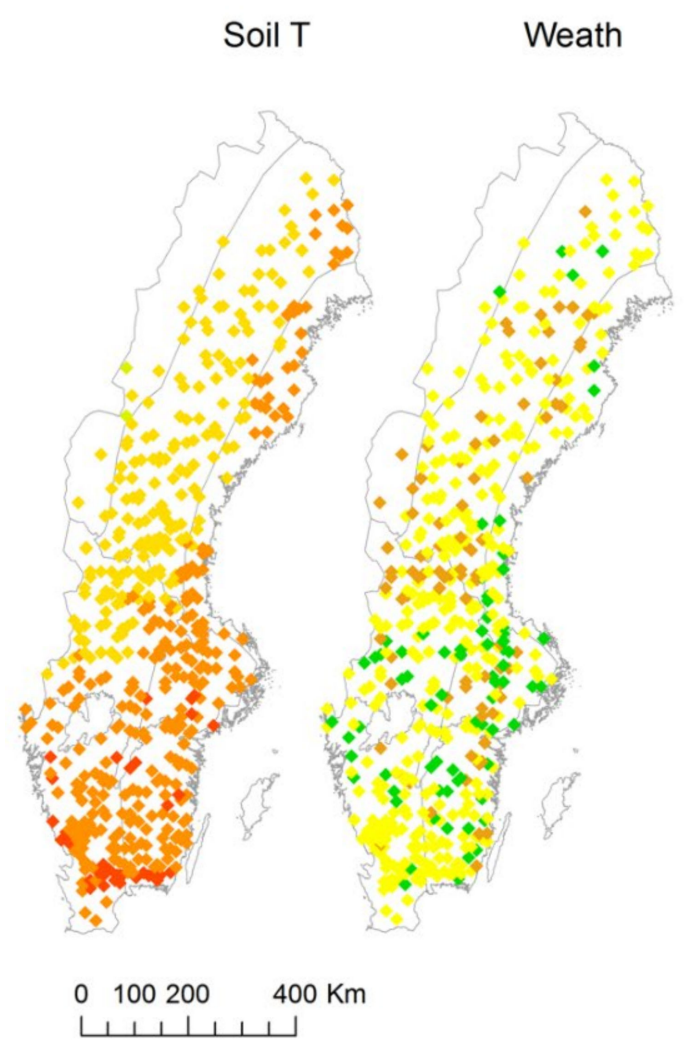

B) ECHAM - BAS

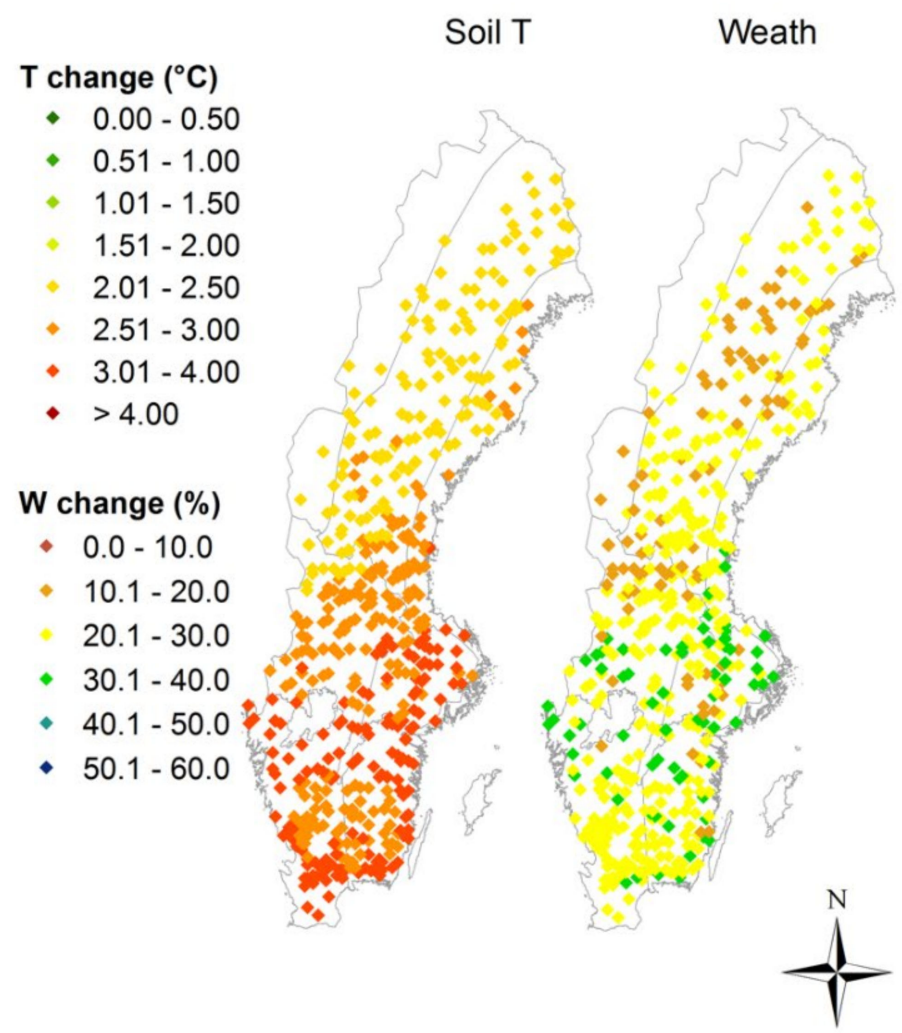

Figure 4. Geographical distribution of changes in soil temperature $\left({ }^{\circ} \mathrm{C}\right)$ and weathering rates $(\%)$ between CCSM (A) and the baseline and between ECHAM (B) and the baseline.

The annual average response of weathering to soil temperature increase is also stronger than that to air temperature increase (Table 2). The average annual weathering rates are 
expected to increase by $6.6 \%$ to $6.7 \%$ per ${ }^{\circ} \mathrm{C}$ increase in air temperature under the CCSM and ECHAM scenarios, respectively. When compared to the increase in soil temperature, weathering rates increments per ${ }^{\circ} \mathrm{C}$ rise to $9.3 \% \cdot{ }^{\circ} \mathrm{C}^{-1}$ and $8.9 \% \cdot{ }^{\circ} \mathrm{C}-1$, respectively, under CCSM and ECHAM. The difference in weathering response to air temperature as compared to soil temperature change is even more expressed during the winter season, but virtually absent during summers (Table 2).

Table 2. Average ( \pm standard deviation) increment of weathering per degree Celsius increase of air (rows 1 and 3) and soil temperature (rows 2 and 4$)\left(\% \cdot{ }^{\circ} \mathrm{C}^{-1}\right)$ for 544 productive coniferous forest sites under CCSM and ECHAM.

\begin{tabular}{ccccc}
\hline & & Annual & Winter & Summer \\
\hline \multirow{2}{*}{ CCSM } & $\Delta_{\text {Weathering }} / \Delta_{\text {AirTemp }}$ & $6.7 \pm 1.6$ & $2.6 \pm 2.1$ & $7.3 \pm 1.6$ \\
& $\Delta_{\text {Weathering }} / \Delta_{\text {SoilTemp }}$ & $9.3 \pm 1.8$ & $8.9 \pm 3.3$ & $7.5 \pm 1.6$ \\
\hline \multirow{2}{*}{ ECHAM } & $\Delta_{\text {Weathering }} / \Delta_{\text {AirTemp }}$ & $6.6 \pm 1.5$ & $4.3 \pm 2.3$ & $7.9 \pm 1.7$ \\
& $\Delta_{\text {Weathering }} / \Delta_{\text {SoilTemp }}$ & $8.9 \pm 1.3$ & $9.4 \pm 1.8$ & $7.7 \pm 1.6$ \\
\hline
\end{tabular}

The increase in weathering correlates positively and significantly to soil temperature increase under both climate scenarios (Figure 5). However, the spread of the correlations remains wide as shown by the low $R^{2}$ values (Figure 5). According to the linear regression (Figure 5), the incremental increase in weathering with soil temperature increase is $6.0 \% \cdot{ }^{\circ} \mathrm{C}^{-1}$ and $8.6 \% \cdot{ }^{\circ} \mathrm{C}^{-1}$ under $\mathrm{CCSM}$ and $\mathrm{ECHAM}$, respectively.
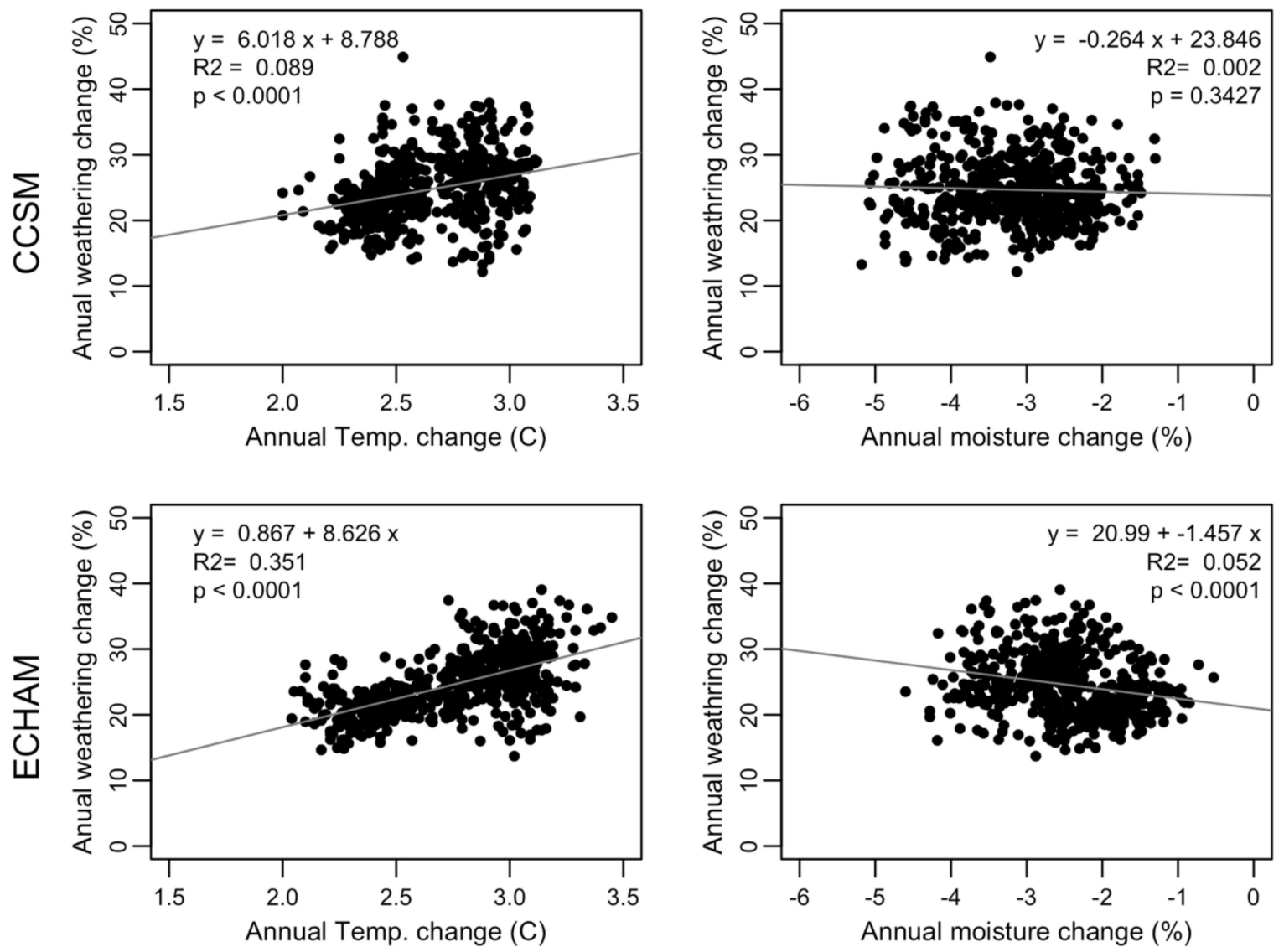

Figure 5. Linear regressions between changes in annual soil temperature and moisture and change in annual weathering rates, under two climate scenarios according to the CCSM (top row) and ECHAM models (bottom row). 
The effect of the change in annual average soil moisture on the weathering rates seems inconclusive (Figure 5). Under the CCSM climate scenario, the correlation between the increase in average annual weathering and the decrease in average annual moisture is not significant, weak, and has a wide spread. Under the ECHAM climate scenario, although the correlation is significant, it has a wide spread and a weak slope (Figure 5).

\subsection{Change in Weathering during the Summer Season}

Unlike the change in annual soil temperatures shown above, the increase in summer soil temperatures is different between the two climate scenarios (Figure 6). Summer soil temperatures are expected to increase by $3.5^{\circ} \mathrm{C}$ to $4.5^{\circ} \mathrm{C}$ according to CCSM, but only by $2.5^{\circ} \mathrm{C}$ to $3.5^{\circ} \mathrm{C}$ according to ECHAM. Yet, although summer soil temperatures would increase the most under CCSM, weathering rates do not follow suite as expected. The effect of the increase in summer soil temperatures on weathering is only significant under the ECHAM scenario, with a substantial slope of the linear regression between the increase in weathering rate and that in soil temperature of $8 \% \cdot{ }^{\circ} \mathrm{C}^{-1}$, but still with a wide spread reflected in the low $R^{2}$ of 0.06 . Under CCSM, the correlation between soil temperature change and the change in weathering is not significant.

\section{A) CCSM - BAS}

Soil T

Weath

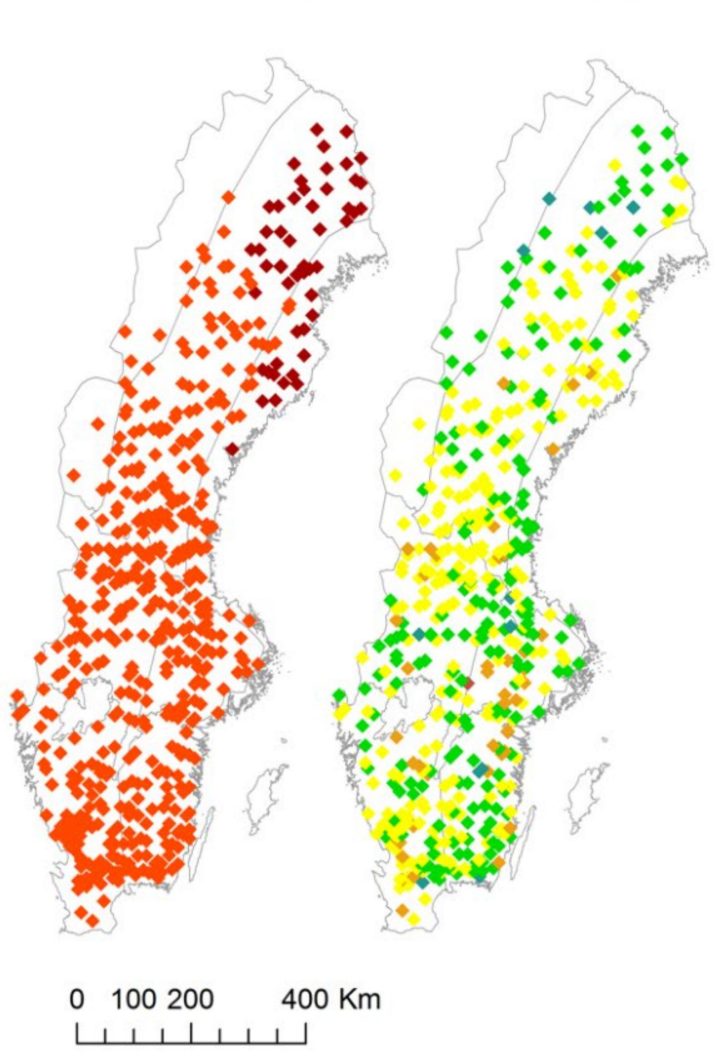

B) ECHAM - BAS

Soil T

Weath

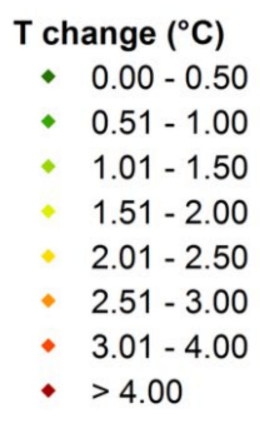

W change (\%)

- $0.0-10.0$

- $10.1-20.0$

$20.1-30.0$

$30.1-40.0$

- 40.1-50.0

- 50.1-60.0

Figure 6. Differences in summer soil temperatures and weathering rates according to (A) - CCSM climate projections and (B)_ECHAM climate projections.

The change in summer soil moisture is substantial with an average of $-7.6 \%(\sigma=1.9 \%)$ under CCSM and $-5.6 \%(\sigma=1.4)$ under ECHAM compared to the no climate change scenario. The change in summer soil moisture is stronger and more consistent than the change in summer precipitation, which shows a reduction by an average of $-5.9 \%(\sigma=8.2 \%)$ under CCSM and an average of $1.1 \%(\sigma=7.8 \%)$ under ECHAM. 
The change in summer weathering correlates significantly to the change in summer soil moisture, with higher increases in weathering corresponding to lower soil moisture reductions (Figure 7).
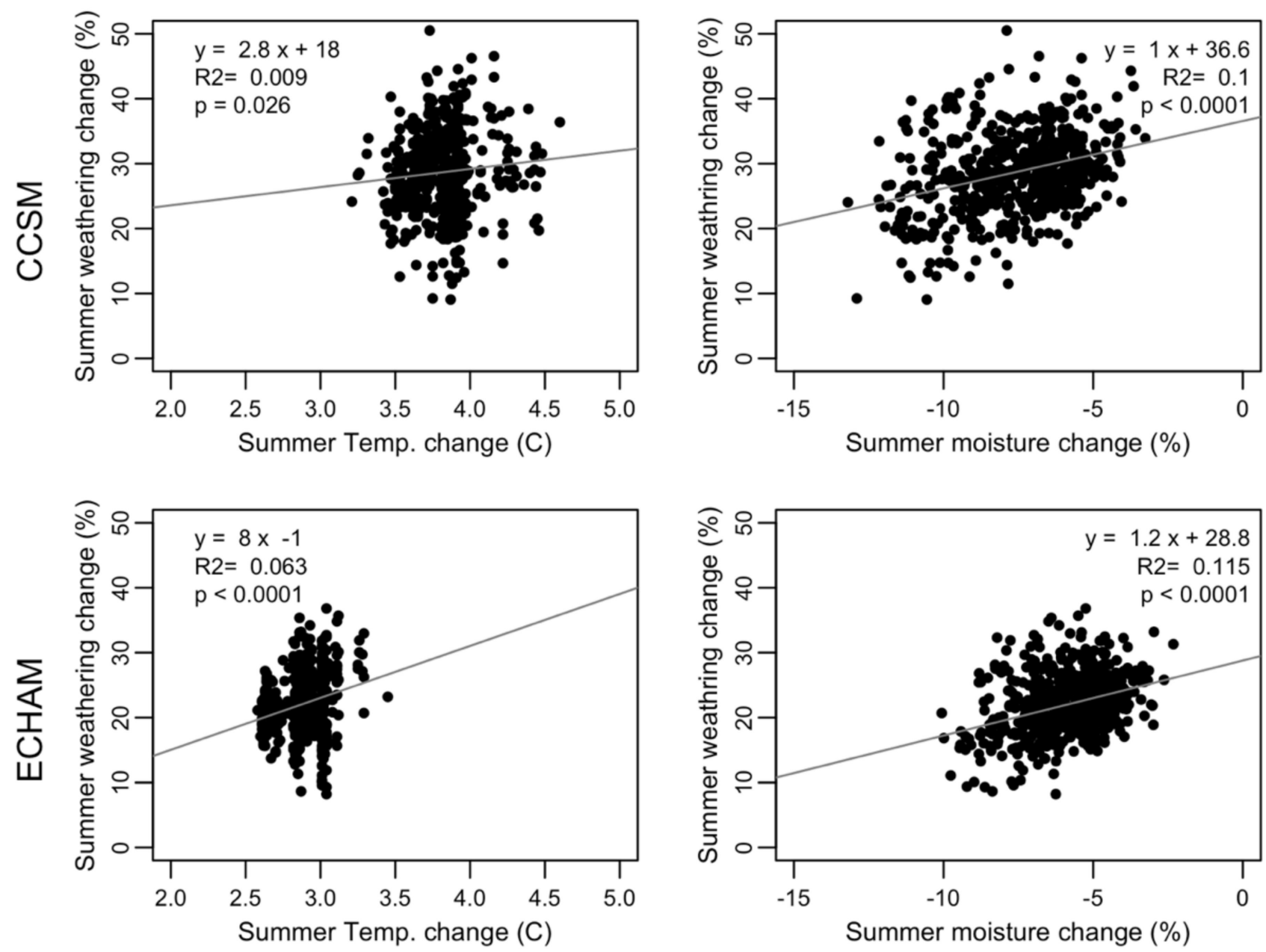

Figure 7. Correlation between the change in weathering rates and the change in soil temperature and moisture for the summer season over the period 2070-2100.

\subsection{Change in Weathering during the Winter Season}

There are clearer regional differences in the change of winter soil temperatures under both scenarios, with a higher increase in the southern half of Sweden (Figure 8). Winter soil temperatures will be up to $2.5^{\circ} \mathrm{C}$ higher under CCSM as compared to the base scenario, and as high as $4^{\circ} \mathrm{C}$ under ECHAM (Figure 8). The geographical pattern of winter temperature increase is also more clearly reflected in the change of weathering rates as compared to the annual and summer changes shown above (Figures 4 and 6). Weathering is expected to increase more strongly following a north to south gradient, and more so under the ECHAM climate scenario (Figure 8).

Under both scenarios, the change in weathering rates correlates significantly and strongly to the change in soil temperature (Figure 9). At the same time, the change in winter soil moisture, from $-0.5 \%$ to $+0.5 \%$, indicates no or marginal further water constrain on weathering under the two climate scenarios. 

A) CCSM - BAS

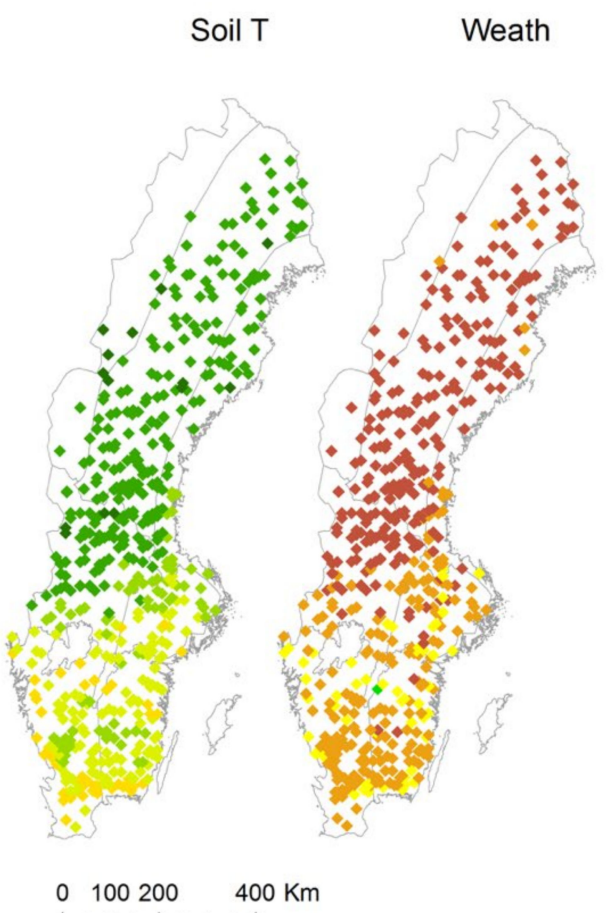

B) ECHAM - BAS

Soil T Weath

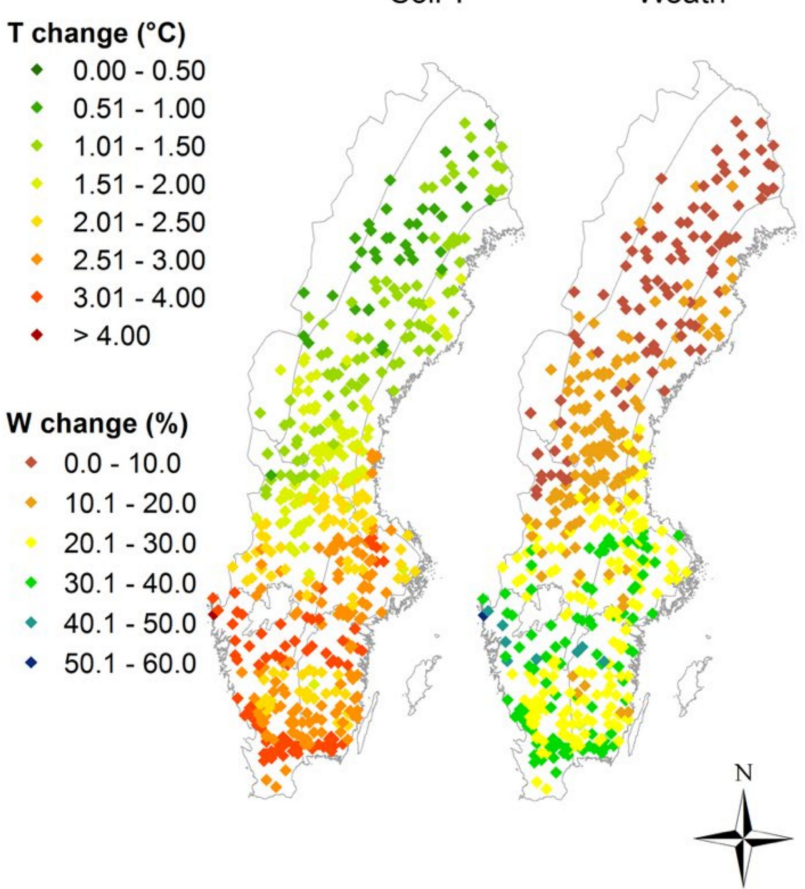

Figure 8. Changes in winter soil temperature and weathering rates under: (A)—CCSM climate and (B)-ECHAM climate.
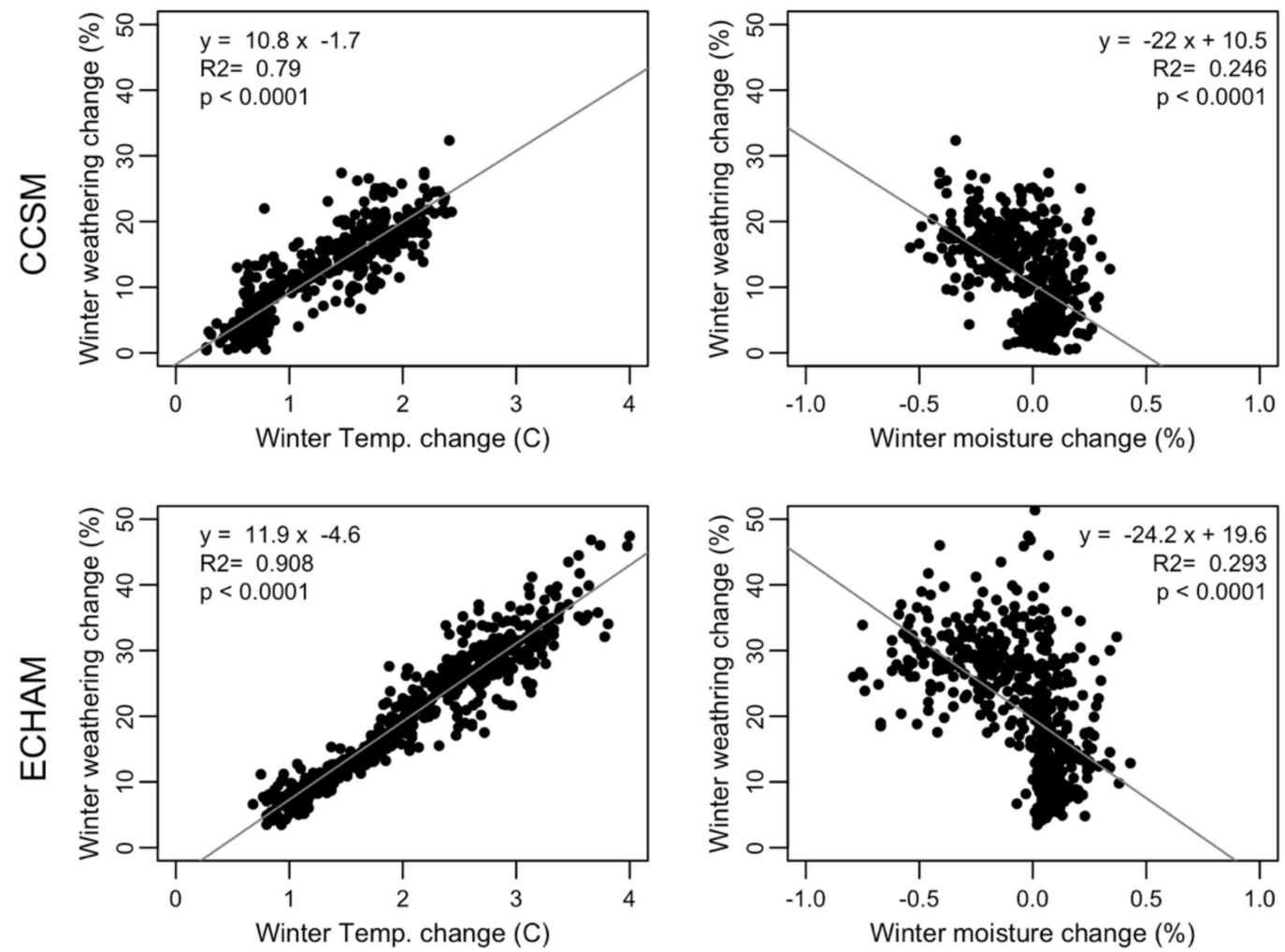

Figure 9. Correlations between the change in winter weathering rates and soil temperature and moisture under CCSM (top row) and ECHAM (bottom row) climate projections. 


\section{Discussion}

The annual weathering rates calculated by ForSAFE are well within the range presented in Akselsson et al. [46], which compiles weathering rates calculated by seven different methods on comparable soils in Sweden. The current annual average weathering calculated in this study, at $0.35 \mathrm{keq} \cdot \mathrm{ha}^{-1} \cdot \mathrm{year}^{-1}$, is similar to an earlier estimate at $0.33 \mathrm{keq} \cdot \mathrm{ha}^{-1} \cdot \mathrm{year}^{-1}$ using the steady state model PROFILE [19]. The PROFILE and ForSAFE models use the same weathering kinetics, but differ fundamentally in how other processes are described. While all fluxes other than weathering (uptake, decomposition and mineralization, percolation, soil moisture content, cation exchange) are dictated based on empirical data in PROFILE, they are all endogenously simulated in ForSAFE, making the latter fully dynamic. In this respect, basing this study on the ForSAFE model differs also from other modelling exercises using model cascades [24-26,47]. We showcase here the feasibility of fully dynamically simulating temporal changes in mineral weathering in response to changes in several simultaneous environmental factors. While the predicted responses cannot be taken precisely, they help identify constraints regulating weathering, and thereby the extent to which the latter can be expected to contribute to different ecosystem services including tree nutrition [48] and runoff water quality [27].

The results of this study confirm earlier conclusions about the importance of hydrology in regulating mineral weathering $[19,23,25,49]$. Here, we also show that seasonal variations in soil moisture are imperative in regulating the role of hydrology in the weathering process. Therefore, while this study increases confidence in current estimates of weathering rates $[19,46,50]$, it also stresses the need to move beyond static or steady state models to provide more credible estimates in a changing future. If considered on an annual basis, the climate scenarios used in this study would not indicate that moisture could be a limiting factor for weathering, as none of the two models predict a decline in annual precipitation. This picture is fundamentally different when looking at seasonal precipitation and temperature patterns. Lower summer precipitation in the future, combined with higher temperatures, exacerbates the reduction of soil moisture, thereby significantly limiting the potential effect of higher temperatures on weathering. This interplay blurs any expected geographical patterns in the response of weathering rates to warming alone (see Figure 6).

The seasonal aspect demonstrated in this study may have direct implications on the provision of base cations necessary for forest growth. Weathering is central for the long term provision of base cations in boreal forest soils [51-53], with uptake predominantly active during the growing season. If weathering rates fail to keep up with uptake during this time window of the year, the observed [54,55] and foreseen [11,19] deterioration in tree nutrition may become worse. Moreover, the importance of seasonality illustrated in this study brings with it an additional methodological aspect. The response of weathering is steered alternatively by the most constraining environmental factor, which changes temporally. Beyond interannual patterns [27], we show in this study that the response of mineral weathering to changes in climate varies considerably within the year, with a clearer dependence on temperature change in winter when water is not limiting, and vice versa. In line with Kronnäs et al. [49], this study strongly indicates that the hierarchy of weathering controls needs to be addressed dynamically, particularly given the prevalent uncertainty in climate projections [56,57]. We do not question the role of statistical and steady state methods to estimate current weathering rates, but instead stress the idea that studies involving future projections need to account for seasonal variations.

The reliability of integrated modelling tools able to estimate mineral weathering $[32,33,49]$ remains dependent on the quality of the input data. In the present study, we used a generalized national database stipulating that 14 different minerals are potentially present at any site in the country. This assumption was tested by Casetou-Gustafson et al. [58], who compared weathering rates generated from the generalized mineralogy database against rates from measurements of mineral occurrence. They concluded that the two approaches gave similar overall weathering rates, but that the weathering rates of specific minerals revealed possible shortcomings that could affect the results of generalized studies such 
as this one. Casetou-Gustafson et al. [58] thus argue for the need to improve site specific information on mineral occurrence and stoichiometry to reduce uncertainties in weathering estimations.

Nevertheless, the generalizations necessary for a national scale study such as this one were not found to cause any marked diversion in weathering estimates compared to other studies (see above). Additionally, while we reservedly express confidence in the model estimates, it is important to see the associated uncertainties in the broader context of ongoing change in climate and forestry intensification. Regional and national scale studies such as this one are necessary to help guide a strategic sector such as forestry in Sweden, by providing an early warning instrument to check expectations about sustained forest health and continued growth into the future.

\section{Conclusions}

The results of this study clearly show the importance of considering soil hydrology and seasonality when estimating the future response of weathering rates to changes in climate. To sustain forest health and growth as well as the supply of base cations to runoff and surface waters, the interplay between different processes (weathering, uptake, runoff) needs to happen in a timely manner. The study shows that the expected increase in weathering in response to climate warming will be weakest in the summer, when the biochemical cycle is most active. This constraint is dictated by lower water availability resulting from lower precipitation and higher temperatures during summers as forecast by two climate models. These results compel two main conclusions: 1 -that estimates of possible gains in weathering as a result of the expected higher temperature have to be conservative and take into account the interplay with moisture, and 2-that more dynamic tools are needed to meet the requirements of this interplay by accommodating feedback mechanisms and higher temporal resolution.

Author Contributions: Conceptualization, S.B. and C.A.; methodology, S.B. and G.Z.; software, S.B.; validation, S.B. and G.Z.; formal analysis, S.B. and C.A.; investigation, S.B.; resources, S.B., C.A. and G.Z.; data curation, S.B. and G.Z.; writing-original draft preparation, S.B.; writing-review and editing, S.B.; visualization, S.B. and G.Z.; project administration, S.B.; funding acquisition, S.B. and C.A. All authors have read and agreed to the published version of the manuscript.

Funding: This research was funded by the Swedish research Council for Environment, Agricultural Sciences and Spatial Planning (FORMAS), through the strong research environment, QWARTS (212-2011-1691).

Institutional Review Board Statement: Not applicable.

Informed Consent Statement: Not applicable.

Data Availability Statement: Not applicable.

Acknowledgments: The author would like to acknowledge David Rayner for providing site level downscaled climate projections.

Conflicts of Interest: The authors declare no conflict of interest.

\section{References}

1. Steffen, W.; Richardson, K.; Rockström, J.; Cornell, S.E.; Fetzer, I.; Bennett, E.M.; Biggs, R.; Carpenter, S.R.; de Vries, W.; de Wit, C.A.; et al. Planetary boundaries: Guiding human development on a changing planet. Science 2015, 347. [CrossRef] [PubMed]

2. IPCC. Climate Change 2014: Synthesis Report. Contribution of Working Groups I, II and III to the Fifth Assessment Report of the Intergovernmental Panel on Climate Change; Core Writing Team, Pachauri, R.K., Meyer, L.A., Eds.; IPCC: Geneva, Switzerland, 2014; $151 \mathrm{p}$.

3. Bennich, T.; Belyazid, S. The route to Sustainability-Prospects and challenges of the bio-based economy. Sustainability $2017,9,887$. [CrossRef]

4. FORMAS: The Swedish Research Council for Environment, Agricultural Sciences and Spatial Planning. Swedish Research and Innovation Strategy for a Bio-Based Economy; Report number R3:2012; FORMAS: Stockholm, Sweden, 2012; ISBN 978-91-540-6068-9. 
5. $\quad$ Lundmark, T.; Bergh, J.; Hofer, P.; Lundström, A.; Nordin, A.; Poudel, B.C.; Sathre, R.; Taverna, R.; Werner, F. Potential roles of Swedish forestry in the context of climate change mitigation. Forests 2014, 5, 557-578. [CrossRef]

6. Börjesson, P.; Hansson, J.; Berndes, G. Future demand for forest-based biomass for energy purposes in Sweden. For. Ecol. Manag. 2017, 383, 17-26. [CrossRef]

7. Cintas, O.; Berndes, G.; Hansson, J.; Poudel, B.C.; Bergh, J.; Börjesson, P.; Egnell, G.; Lundmark, T.; Nordin, A. The potential role of forest management in Swedish scenarios towards climate neutrality by mid century. For. Ecol. Manag. 2017, 383, 73-84. [CrossRef]

8. De Jong, J.; Akselsson, C.; Egnell, G.; Löfgren, S.; Olsson, B.A. Realizing the energy potential of forest biomass in Sweden-How much is environmentally sustainable? For. Ecol. Manag. 2017, 383, 3-16. [CrossRef]

9. Schöpp, W.; Posch, M.; Mylona, S.; Johansson, M. Long-term development of acid deposition (1880-2030) in sensitive freshwater regions in Europe. Hydrol. Earth Syst. Sci. 2003, 7, 436-446. [CrossRef]

10. Warfvinge, P.; Bertills, U. Recovery from Acidification in the Natural Environment_Present Knowledge and Future Scenarios; Swedish Environmental Protection Agency: Stockholm, Sweden, 1999.

11. Iwald, J.; Löfgren, S.; Stendahl, J.; Karltun, E. Acidifying effect of removal of tree stumps and logging residues as compared to atmospheric deposition. For. Ecol. Manag. 2013, 290, 49-58. [CrossRef]

12. Akselsson, C.; Hultberg, H.; Karlsson, P.E.; Pihl Karlsson, G.; Hellsten, S. Acidification trends in south Swedish forest soils 1986-2008: Slow recovery and high sensitivity to sea- salt episodes. Sci. Total Environ. 2013, 444, 271-287. [CrossRef]

13. Pihl Karlsson, G.; Akselsson, C.; Hellsten, S.; Karlsson, P.E. Reduced European emissions of S and N: Effects on air concentrations, deposition and soil water chemistry in Swedish forests. Environ. Pollut. 2011, 159, 3571-3582. [CrossRef]

14. Belyazid, S.; Westling, O.; Sverdrup, H. Modelling changes in forest soil chemistry at 16 Swedish coniferous forest sites following deposition reduction. Environ. Pollut. 2006, 144, 596-609. [CrossRef] [PubMed]

15. Akselsson, C.; Belyazid, S. Critical biomass harvesting-Applying a new concept for Swedish forest soils. For. Ecol. Manag. 2018, 409, 67-73. [CrossRef]

16. Zetterberg, T.; Olsson, B.A.; Löfgren, S.; von Brömssen, C.; Brandtberg, P.O. The effect of harvest intensity on long-term calcium dynamics in soil and soil solution at three coniferous sites in Sweden. For. Ecol. Manag. 2013, 302, 280-294. [CrossRef]

17. Claesson, S. Skogliga Konsekvensanalyser 2008 -SKA-VB 08; Rapport 25; Skogsstyrelsen: Jönköping, Sweden, 2008. (In Swedish)

18. Akselsson, C.; Westling, O.; Sverdrup, H.; Holmqvist, J.; Thelin, G.; Uggla, E.; Malm, G. Impact of harvest intensity on long-term base cation budgets in Swedish forest soils. Water Air Soil Pollut. Focus 2007, 7, 201-210. [CrossRef]

19. Akselsson, C.; Olsson, J.; Belyazid, S.; Capell, R. Can increased weathering rates due to future warming compensate for base cation losses following whole-tree harvesting in spruce forests? Biogeochemistry 2016, 128, 89-105. [CrossRef]

20. Aherne, J.; Posch, M.; Forsius, M.; Lehtonen, A.; Härkönen, K. Impact of forest biomass removal on soil nutrient status under climate change: A catchment-based modelling study for Finland. Biogeochemistry 2012, 107, 471. [CrossRef]

21. Oelkers, E.H.; Schott, J. An experimental study of enstatite dissolution rates as a function of $\mathrm{pH}$, temperature, and aqueous $\mathrm{Mg}$ and Si concentration, and the mechanism of pyroxene/pyroxenoid dissolution. Geochim. Et Cosmochim. Acta 2001, 65, 1219-1231. [CrossRef]

22. Sverdrup, H.; Warfvinge, P. Calculating field weathering rates using a mechanistic geochemical model profile. Appl. Geochem. 1993, 8, 273-283. [CrossRef]

23. Eiriksdottir, E.S.; Gislason, S.R.; Oelkers, E.H. Does temperature or runoff control the feedback between chemical denudation and climate? Insights from NE Iceland. Geochim. Et Cosmochim. Acta 2013, 107, 65-81. [CrossRef]

24. Goddéris, Y.; François, L.M.; Probst, A.; Schott, J.; Moncoulon, D.; Labat, D.; Viville, D. Modelling weathering processes at the catchment scale: The WITCH numerical model. Geochim. Et Cosmochim. Acta 2006, 70, 1128-1147. [CrossRef]

25. Godderis, Y.; Brantley, S.L.; Francois, L.M.; Schott, J.; Pollard, D.; Deque, M.; Dury, M. Rates of consumption of atmospheric CO2 through the weathering of loess during the next $100 \mathrm{yr}$ of climate change. Biogeosciences 2013, 10, 135-148. [CrossRef]

26. Banwart, S.A.; Berg, A.; Beerling, D.J. Process-based modeling of silicate mineral weathering responses to increasing atmospheric CO2 and climate change. Glob. Biogeochem. Cycles 2009, 23, 1-13. [CrossRef]

27. Erlandsson, M.; Oelkers, E.H.; Bishop, K.; Sverdrup, H.; Belyazid, S.; Ledesma, J.L.J.; Kähler, S.J. Spatial and temporal variations of base cation release from chemical weathering on a hillslope scale. Chem. Geol. 2016, 441, 1-13. [CrossRef]

28. Palandri, J.L.; Kharaka, Y.K. A Compilation of Rate Parameters of Water-mineral Interaction Kinetics for Application to Geochemical Modeling; Geological Survey: Menlo Park, CA, USA, 2004.

29. Oelkers, E.H.; Schott, J.; Devidal, J.L. The effect of aluminum, pH, and chemical affinity on the rates of aluminosilicate dissolution reactions. Geochim. Et Cosmochim. Acta 1994, 58, 2011-2024. [CrossRef]

30. Wallman, P.; Svensson, M.; Sverdrup, H.; Belyazid, S. ForSAFE-An integrated process-oriented forest model for long-term sustainability assessments. For. Ecol. Manag. 2005, 207, 19-36. [CrossRef]

31. Zanchi, G.; Belyazid, S.; Akselsson, C.; Yu, L. Modelling the effects of management intensification on multiple forest services: A Swedish case study. Ecol. Model. 2014, 284, 48-59. [CrossRef]

32. Belyazid, S.; Phelan, J.; Nihlgård, B.; Sverdrup, H.; Driscoll, C.; Fernandez, I.; Aherne, J.; Teeling-Adams, L.; Arsenault, M.; Cleavitt, N.; et al. Assessing the Effects of Climate Change and Air Pollution on Soil Properties and Plant Diversity in Northeastern, U.S. hardwood forests: Model Setup and Evaluation. Water Air Soil Pollut. 2019, 230, 106. [CrossRef]

33. Yu, L.; Zanchi, G.; Akselsson, C.; Wallander, H.; Belyazid, S. Modelling the forest phosphorus nutrition in a southwestern Swedish forest site. Ecol. Model. 2018, 369, 88-100. [CrossRef] 
34. Phelan, J.; Belyazid, S.; Kurz, D.; Guthrie, S.; Cajka, J.; Sverdrup, H.; Waite, R. Estimation of soil base cation weathering rates with the PROFILE model to determine critical loads of acidity for forested ecosystems in Pennsylvania, USA: Pilot Application of a Potential National Methodology. Water Air Soil Pollut. 2014, 225, 2109-2128. [CrossRef]

35. Belyazid, S.; Zanchi, G. Water limitation can negate the effect of higher temperatures on carbon sequestration. Eur. J. For. Res. 2019, 138, 287-297. [CrossRef]

36. Warfvinge, P.; Sverdrup, H. Calculating critical loads of acid deposition with PROFILE-A steady-state soil chemistry model. Water Air Soil Pollut. 1992, 63, 119-143. [CrossRef]

37. Alveteg, M. Projecting Regional Patterns of Future Soil Chemistry Status in Swedish Forests using SAFE. Water Air Soil Pollut. Focus 2004, 4, 49-59. [CrossRef]

38. Hägglund, B. En ny Svensk Riksskogstaxering (A New Swedish National Forest Survey); Report 37; Swedish University of Agricultural Sciences: Uppsala, Sweden, 1985; (In Swedish with English Summary).

39. Akselsson, C. Regional Nutrient Budgets in Forest Soils in a Policy Perspective. Ph.D. Thesis, Department of Chemical Engineering, Lund University, Lund, Sweden, 2005.

40. Simpson, D.; Benedictow, A.; Berge, H.; Bergström, R.; Emberson, L.D.; Fagerli, H.; Flechard, C.R.; Hayman, G.D.; Gauss, M.; Jonson, J.E.; et al. The EMEP MSC-W chemical transport model-Technical description. Atmos. Chem. Phys. 2012, 12, 7825-7865. [CrossRef]

41. Persson, C.; Langner, J.; Robertson, L. Air pollution assessment studies for Sweden based on the match model and air pollution measurements. In Air Pollution Modeling and Its Application XI; Gryning, S.E., Schiermeier, F.A., Eds.; Springer: Boston, MA, USA, 1996; pp. 127-134.

42. Swedish Forest Agency. Gallringsmallar—Södra Sverige; Skogsstyrelsen: Jönköping, Sweden, 1985.

43. Swedish Forest Agency. Gallringsmallar-Norra Sverige; Skogsstyrelsen: Jönköping, Sweden, 1985.

44. Jacobson, S.; Sikström, U.; Nyström, K.; Övergaard, B. INGVAR-Thinning Schedules and Forest Management Planning Tool; SkogForsk: Uppsala, Sweden, 2008; (In Swedish with English Summary).

45. Rayner, D.; (Gothenburg University, Gothenburg, Sweden). Personal communication, 2010.

46. Akselsson, C.; Belyazid, S.; Stendahl, J.; Finlay, R.; Olsson, B.A.; Erlandsson Lampa, M.; Wallander, H.; Gustafsson, J.P.; Bishop, K. Weathering rates in Swedish forest soils. Biogeosciences 2019, 16, 4429-4450. [CrossRef]

47. Houle, D.; Marty, C.; Augustin, F.; Dermont, G.; Gagnon, C. Impact of climate change on soul hydro-climatic conditions and base cations weathering rates in forested watersheds in eastern Canada. Front. For. Glob. Chang. 2020, 3, 111. [CrossRef]

48. Uhlig, D.; von Blanckenburg, F. How slow rock weathering balances nutrient loss during fast forest floor turnover in montane, temperate forest ecosystems. Front. Earth Sci. 2015, 7, 159. [CrossRef]

49. Kronnäs, V.; Akselsson, C.; Belyazid, S. Dynamic modelling of weathering rates-The benefit over steady-state modelling. Soil 2019, 5, 33-47. [CrossRef]

50. Stendahl, J.; Akselsson, C.; Melkerud, P.A.; Belyazid, S. Pedon-scale silicate weathering: Comparison of the PROFILE model and the depletion method at 16 forest sites in Sweden. Geoderma 2013, 211, 65-74. [CrossRef]

51. Van der Heijden, G.; Legout, A.; Midwood, A.; Craig, C.-A.; Pollier, B.; Ranger, J.; Dambrine, E. Mg and Ca root uptake and vertical transfer in soils assessed by an In Situ ecosystem-scale multi-isotopic (26Mg \& 44Ca) tracing experiment in a beech stand (Breuil-Chenue, France). Plant Soil 2013, 369, 33-45.

52. Van der Heijden, G.; Dambrine, E.; Pollier, B.; Zeller, B.; Ranger, J.; Legout, A. Mg and Ca uptake by roots in relation to depth and allocation to aboveground tissues: Results from an isotopic labeling study in a beech forest on base-poor soil. Biogeochemistry 2015, 122, 375-393. [CrossRef]

53. Duchesne, L.; Houle, D. Impact of nutrient removal through harvesting on the sustainability of the boreal forest. Ecol. Appl. 2008, 18, 1642-1651. [CrossRef] [PubMed]

54. Braun, S.; Tresch, S.; Augustin, S. Soil solution in Swiss forest stands: A 20 year's time series. PLoS ONE 2020, 15, e0227530. [CrossRef] [PubMed]

55. Jonard, M.; Legout, A.; Nicolas, M.; Dambrine, E.; Nys, C.; Ulrich, E.; van der Perre, R.; Ponette, Q. Deterioration of Norway spruce vitality despite a sharp decline in acid deposition: A long-term integrated perspective. Glob. Chang. Biol. 2012, 18, 711-725. [CrossRef]

56. Visser, H.; Folkert, R.J.M.; Hoekstra, J.; de Wolff, J.J. Identifying Key Sources of Uncertainty in Climate Change Projections. Clim. Chang. 2000, 45, 421-457. [CrossRef]

57. Jones, R.N. Managing uncertainty in climate change projections-Issue for impact assessment. Clim. Chang. 2000, 45, 403-419. [CrossRef]

58. Casetou-Gustafson, S.; Hillier, S.; Akselsson, C.; Simonsson, M.; Stendahl, J.; Olsson, B. Comparison of measured (XRPD) and modeled (A2M) soil mineralogies: A study of some Swedish forest soils in the context of weathering rate predictions. Geoderma 2018, 310, 77-88. [CrossRef] 